\title{
Abstracts
}

\section{Hannes Schammann}

\section{Reassessing the Opinion-Policy Gap in Migration Studies}

The PEGIDA Movement and how it relates to German Immigration Policies

Known by its German acronym, PEGIDA, the movement of "Patriotic Europeans Against the Islamization of the Occident", has dominated the public debate on immigration policies in Germany in winter 2014/15. It has also attracted the attention of political scientists specializing in protest and social movement studies. Scholars of migration policy, however, have hardly contributed to the scientific debate on PEGIDA. Part of that reluctance might result from the belief that the PEGIDA-phenomenon is just another proof of the so-called opinion-policy gap hypothesis in migration studies. Freeman (1995) famously argued that there is a gap between public opinion which is constantly calling for restrictive immigration policies and factual immigration policies in Western democracies, which are becoming more expansive over time. This article challenges that view on PEGIDA in particular and on the opinion-policy gap hypothesis in general. It does so by demonstrating how the PEGIDA movement in Germany relates to national immigration policies: Firstly, PEGIDA has not accepted the profound change in German policies of identity and belonging which has taken place over the last decade. Therefore, the relation between these policies and the movement's claims can be described as a 'policy-opinion lag'. Secondly, PEGIDA approves the general orientation of the institutional framework of migration policy toward national security but seeks to intensify the corresponding measures. This relation I will call an 'intensity gap'. Thirdly, 'opinion-policy congruence' can be observed: PEGIDA and current German immigration policies share an economic view on migration. 
Tim Niendorf

The Downfall? The Scottish Independence Referendum and the Labour Party's Electoral Decline in Scotland

The 2015 general election saw the biggest electoral earthquake in Scottish history with a widespread collapse of Labour's support and the SNP's narrow failure to win a majority of the popular vote. The article illuminates the reasons for Labour's unpreceded decline in its former stronghold. It is argued that this resulted from Labour's ill-fated campaign during the independence referendum of 2014, which seriously damaged its perception as defender of Scottish interests. Based on the results of the referendum and the general elections of 2010 and 2015, it is shown that Labour's losses in the different Scottish regions were effectively a function of the referendum's yes vote. It is also demonstrated that the SNP's success during the general election almost exclusively depended on Labour's disastrous performance. 


\section{(T) WOCHEN SCHAU VERLAG}

... ein Begriff für politische Bildung

Wolfgang Benz

\section{Antisemitismus}

\section{Präsenz und Tradition eines Ressentiments}

Objektive Kriterien, was Antisemitismus ist, in welchen Formen er bei uns vorkommt und wie Judenfeindschaft von Israelkritik abzugrenzen ist, sind für eine differenzierte Betrachtung des Phänomens unentbehrlich. In seinem neuen Buch fasst der angesehene Antisemitismusforscher Wolfgang Benz Arbeitsergebnisse und Erkenntnisse aus seiner langjährigen Beschäftigung mit dem langlebigsten Vorurteil der menschlichen Geschichte und den Folgen zusammen. Das Buch bietet ein Kompendium, das ohne gelehrte Attitüde, aber mit aller wissenschaftlichen Akribie und Sorgfalt gewonnene Einsichten bündelt.

ISBN 978-3-7344-0104-6, 256 S., $€ 14,80$

Wolfgang Benz (Hrsg.)

\section{Ressentiment und Konflikt}

\section{Vorurteile und Feindbilder im Wandel}

Vorurteile und Feindbilder bestimmen alle Aspekte des Zusammenlebens: die Ebenen der Politik, das soziale Umfeld des Alltags, die ökonomische Situation, den Arbeits- und Wohnungsmarkt, den privaten Umgang der Menschen, ihre Ängste und Erwartungen. Die Betrachtung der aus Ressentiments erwachsenden Probleme und Konflikte verlangt daher den interdisziplinären Zugriff. Historiker, Sozial- und Wirtschaftswissenschaftler kommen in diesem Buch ebenso zu Wort wie Vertreterinnen und Vertreter der Psychologie, der Rechts- und der Islamwissenschaft, der Philosophie, der Menschenrechte und der Integrationsforschung. Das Buch zeigt nachdrücklich auf, wie aktuelle politische Probleme durch Vorurteile beeinflusst werden.

Herausgegeben im Auftrag des Sir Peter Ustinov Instituts für Vorurteilsforschung, Wien

ISBN 978-3-7344-0009-4, 240 S., € 24,80

\section{Vorurteile}


Vorurteile und Feindbilder im Wandel

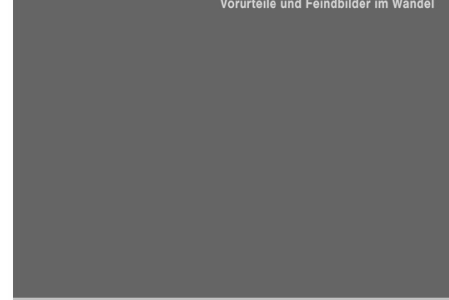

WOCHEN

WISSENSCHAFT 


\section{Aktuelle Highlights}

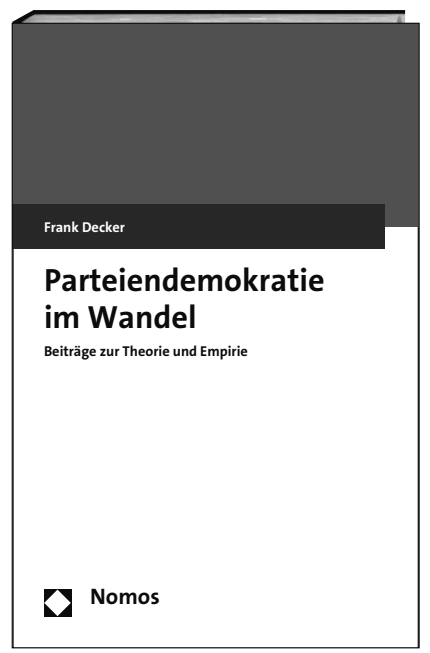

\section{Parteiendemokratie im Wandel}

Beiträge zur Theorie und Empirie

Von Prof. Dr. Frank Decker

2015, ca. 240 S., brosch., ca. 34,- $€$

ISBN 978-3-8487-2500-7

Erscheint ca. Oktober 2015

www.nomos-shop.de/25299

Die bundesdeutsche Parteienlandschaft ist in Bewegung geraten. So wie das Parteiensystem unterliegen auch die Parteien im Einzelnen heute einem starken Wandel. Dieser schlägt sich in ihrem Verhältnis zur Gesellschaft, ihrer Rolle im Staat und in ihrem Innenleben nieder. Der Band behandelt die drei Analyseebenen aus theoretischer wie empirischer Sicht.

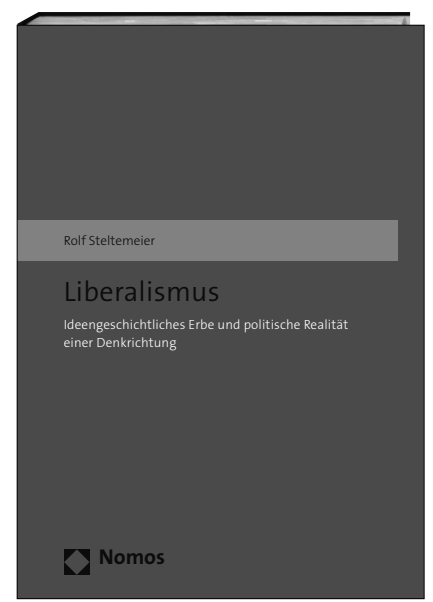

\section{Liberalismus}

Ideengeschichtliches Erbe und politische Realität einer Denkrichtung

Von MinDirig Dr. Rolf Steltemeier

2015, 703 S., geb., 98,- $€$

ISBN 978-3-8487-2236-5

www.nomos-shop.de/24593

Ein Muss für jeden, der sich mit dem Liberalismus auseinandersetzt und praktische Denkanstöße und Hilfestellungen bei der Formulierung von liberalen Grundsätzen erwartet. Der ideengeschichtliche Kern des politischen Liberalismus wird in den vier Kernbereichen Bürgerrechte, Wirtschaftspolitik, Sozialpolitik und Außenpolitik herausgearbeitet.

Bestellen Sie jetzt telefonisch unter 07221/2104-37. 